\title{
Creative Collaboration in Higher Education
}

Ifan, Gwawr; Hodges, Rhian Sian

\section{Academic Biliteracies}

Published: 31/03/2017

Peer reviewed version

Cyswllt i'r cyhoeddiad / Link to publication

Dyfyniad o'r fersiwn a gyhoeddwyd / Citation for published version (APA):

Ifan, G., \& Hodges, R. S. (2017). Creative Collaboration in Higher Education: A Coleg Cymraeg Cenedlaethol case-study. In D. M. Palfreyman, \& C. van der Walt (Eds.), Academic Biliteracies : Multilingual Repertoires in Higher Education Multilingual Matters.

Hawliau Cyffredinol / General rights

Copyright and moral rights for the publications made accessible in the public portal are retained by the authors and/or other copyright owners and it is a condition of accessing publications that users recognise and abide by the legal requirements associated with these rights.

- Users may download and print one copy of any publication from the public portal for the purpose of private study or research.

- You may not further distribute the material or use it for any profit-making activity or commercial gain

- You may freely distribute the URL identifying the publication in the public portal ?

Take down policy

If you believe that this document breaches copyright please contact us providing details, and we will remove access to the work immediately and investigate your claim. 


\title{
Creative Collaboration in Higher Education: A Coleg Cymraeg Cenedlaethol case-study
}

\author{
Dr Gwawr Ifan, Dr Rhian Hodges, Bangor University
}

\section{Introduction}

Firstly, this chapter sets out to explain the context of bilingual higher education in Wales, detailing the development of the Coleg Cymraeg Cenedlaethol, and will focus on the pedagogical practices used in bilingual secondary and higher education. It will discuss the incentive behind the development of an interdisciplinary module, bringing together two different academic schools in a higher education institution. Though delivered through the medium of a minority language, the advantages of actively engaging in the use of two languages in terms of resources and assessment methods will be considered. Focusing on this module as a case study, the chapter aims to evaluate its effectiveness, and will consider the pedagogical merits of studying a module of its kind in terms of a) interdisciplinary teaching in a minority language, and $b$ ) enhancing opportunities for translanguaging and biliteracy practices. It will also suggest recommendations for the further development of similar models in the future.

\section{Background}

Wales is a devolved nation forming a distinct part of the UK. It is a country with its own unique language which is amongst the oldest Celtic languages in Europe. Of a population of 3.1 million people, 562,000 people in Wales are able to speak Welsh (Office for National Statistics, 2011). However, according to the Welsh Language Use in Wales 2013-2015 survey, only 67\% of Welsh speakers perceive their written Welsh language skills to be 'good' or 'very good' (Welsh Government and Welsh Language Commissioner, 2015). Whilst still considered a minority language, it is a main tool of communication for a high percentage of the population. As a result, Welsh-medium education for all ages is at the forefront of policy for the Welsh Government (2013), whose vision is:

an education and training system that responds in a planned way to the growing demand for Welsh-medium education, reaches out to and reflects our diverse communities and enables an increase in the number of people of all ages and backgrounds who are fluent in Welsh and able to use the language with their families, in their communities and in the workplace. (Welsh Government, 2010, p.4)

In 2011, 30\% of Welsh speakers were aged between 3-15 years old (Office for National Statistics, 2011), and this young demographic is largely due the success of firmly established Welsh-medium education (Hodges, 2012; Thomas and Williams, 2013). While Welsh-medium schools offer education primarily through the medium of Welsh, they could also be considered to be bilingual schools, as both English and Welsh languages are naturally used in order to 'develop every individual to be confidently bilingual' (Lewis, 2011, p.67).

Despite the success of bilingual secondary education, higher education continues to be a constant battleground for competing language choices (G.R. Jones, 2010; Davies and Trystan, 2012). In order to satisfy the need for linguistic provision and linguistic progression from secondary schools to higher education, a steering group for Welsh Medium Provision in Higher Education was developed by the Higher Education Funding Council for Wales [HEFCW] in 2004, aiming to 'set out actions to create a sustainable system for Welsh medium higher education in the future' (HEFCW, 2004). In time, this

Creative Collaboration in Higher Education: A Coleg Cymraeg Cenedlaethol case-study - Error! No text of specified style in document. (3-Mar-17)
4-disciplines-A Ifan_Hodges final (3).docx 
prompted the development of the Centre for Welsh Medium Higher Education to implement HEFCW's strategy, which ultimately led to the establishment of the Coleg Cymraeg Cenedlaethol [Welsh-medium National College] as a formally incorporated company in 2011.

The Coleg Cymraeg Cenedlaethol is a virtual learning college that works with Universities across Wales to train new Welsh-medium researchers and lecturers and provides funding to develop cross-institutional Welsh medium opportunities for students. It is currently possible for Welsh-speaking students to study over 500 courses entirely or partly through the medium of Welsh, with scholarships of up to $f 5000$ awarded to students who study courses in Welsh (Coleg Cymraeg Cenedlaethol, 2014a).

Of all Welsh Universities, Bangor University, a traditional university established in 1884, offers the highest number of Welsh-medium modules, and more students choose to study their subjects in Welsh than at any other higher education institution (Coleg Cymraeg Cenededlaethol, 2014b). As the University is situated in an area where, on average, $69 \%$ of the population speak Welsh, 'Playing a leading role in Welsh language and culture, both locally and nationally' is one of the institution's key priorities (Bangor University, 2013, p. 2). In 2010/11, the University had 9,200 full-time students and 1,980 part-time students. Of those, 1,795 noted that they could speak Welsh fluently and another 743 noted that they could speak some Welsh or were learning Welsh (Bangor University, 2013). The University therefore considers developing and enhancing Welsh-medium modular provision to be of the utmost importance in order to fully meet the needs of these students.

Although the development of the Coleg Cymraeg Cenedlaethol is of great significance and value for the future provision of Welsh-medium higher education, the authors of this article, who are Coleg Cymraeg Cenedlaethol lecturers at Bangor University, were faced with linguistic challenges which led to the case study discussed in this chapter.

B. Jones (2010) observes that there is a 'kaleidoscopic variety' (Baker, 1993, p.15) of bilingual pedagogical practices used in education in Wales. In higher education in Wales, following the development of the Coleg Cymraeg Cenedlaethol and the increase in Welsh-medium education, a constant challenge faced by lecturers and practitioners is to encourage the simultaneous use of two languages - Welsh and English - within students' studies. Biliteracy can therefore be used to enrich pedagogical practice and educational experience, through

the ongoing, dynamic development of concepts and expertise for thinking, listening, speaking, reading, and writing in two languages. (Reyes, 2006, p.269)

Huang (1995, p. 276) highlights the complex influences that shape biliteracy practices, such as the value of skills, sentiments attached to the languages, judgments of significant others, and experience of formal schooling (Huang, 1995, p.276).

By sensitively constructing biliteracy practices - both written and oral components in higher education (Hornberger, 2007, p.3, see also introductory chapter), students are given the opportunity to engage and strengthen their own cultural identity and self-esteem (Huang, 1995) whilst, at the same time, embracing the wider linguistic and social context that is available to them as bilinguals.

Code-switching is a specific example of a strategy used regularly in oral biliteracy development which has been scrutinised by educational researchers in Wales (e.g. Robert, 2009; Clapham, 2012). Code-switching as a technique to introduce and normalise the use of a given language in schooling is a key aspect of emergent biliteracy (Reyes, 2006). As students become more confident users of two academic languages, they may move beyond code-switching to read in one language and discuss in another, or listen to one language and make notes in another: the type of behaviour described as 'translanguaging' by Williams (1994). Whilst code-switching may be more prevalent in younger children

Dr Gwawr Ifan, Dr Rhian Hodges, Bangor University - Error! No text of specified style in document. (3-Mar-17)
4-disciplines-A Ifan_Hodges final

(3).docx 
as they develop initial biliteracy skills, 'translanguaging' (Williams, 1994) however, may be a more suitable pedagogical tool that occurs naturally in Welsh-medium higher education:

The notion of translanguaging refers broadly to how bilingual students communicate and make meaning by drawing on and intermingling linguistic features from different languages. (Hornberger \& Link, 2012, p.240)

A common concern amongst students studying any subject through the medium of Welsh is the need to depend regularly on English-medium sources, therefore, translanguaging may be considered not only 'necessary, but desirable educational practice' (Hornberger \& Link, 2012, p.239) in bilingual communities.

However, it could be argued that Welsh-medium higher-education teaching has traditionally offered what García (2009) refers to as 'double monolingualism'. Previously, in an attempt to fill the gap in Welsh-language provision, academic schools have often developed translated versions of modules previously only available in English, sometimes gaining funding to translate core texts from English into Welsh (e.g. Grout \& Palisca, 1997). It could be argued that such practices can undermine the unique context of the Welsh language, and therefore do not embrace the benefits of biliteracy, where important skills for bilingual students are developed. According to Garcia's theory, rather than creating another 'monolingual' module, it may be considered better practice to embrace the natural bilingual culture in which Welsh students live, communicate and work. Rather than restricting students to the limited resources available in Welsh, it may be more beneficial to broaden their horizons, and to educate them in the widest cultural and linguistic context possibly available to them. Thus their bilingualism may be seen as an academic skill, contributing towards their academic progression, rather than limiting their resources.

As students who choose to study in Welsh are in a minority within Welsh universities, they will usually have to study in relatively small sized classes. This escalates difficulties for the lecturer to use more innovative teaching methods that are readily available with larger classes, e.g. group work, peer-learning etc. As breaking traditional institutional boundaries is encouraged by the Coleg Cymraeg Cenedlaethol, one option that occurred to the authors when developing new programme offerings was the development of an interdisciplinary module, building on class sizes by combining student groups from different Schools and Colleges. In contrast to the concept of the 'subject approach', this model:

incorporates and connects key concepts and skills from many disciplines into the presentation of a single unit. (Adeyemni, 2010, p.11-12)

Interdisciplinary teaching is becoming an increasingly customary practice in higher education, and is a progressively important aspect for university graduates considering the complexity and multidimensionality' (King, 2010) of graduates' careers. It is considered to enrich student understanding; allow students to gain and apply knowledge, develop skills and strategies and construct a more integrated web of knowledge and information (Adeyemni, 2010). It has also been found, for example, that medical students following an interdisciplinary module 'felt strongly that interacting with residents from other disciplines increased the value of the course' (Julian et al, 2007). Because of the increase in class sizes, such provision may be more appropriate for language-minority students as it is less isolated (Malarz, 1998). By allowing academic socialization (Lea \& Street, 2006) to take place in interdisciplinary modules, it is possible to bring minority language speakers together to create a stronger sense of community, in contrast with what would previously have been a limited community of minority language students in individual academic schools.

Dr Gwawr Ifan, Dr Rhian Hodges, Bangor University - Error! No text of specified style in document. (3-Mar-17)
4-disciplines-A Ifan_Hodges final

(3).docx 


\section{Case study}

After receiving a grant from the Coleg Cymraeg Cenedlaethol to develop an interdisciplinary module through the medium of Welsh, the 'Cymdeithaseg Cerddoriaeth yng Nghymru' [Sociology of Music in Wales] module was created by two coordinators from the School of Music and the School of Social Sciences, Bangor University. The module combined key themes from sociology and music and drew upon cultural, musical and social factors often unique to the Welsh language and Wales. In the process of validation, it was argued that the establishment of this module would combine rare specialist knowledge in Music and Social Science through the medium of Welsh, and create larger teaching groups enabling the use of a variety of teaching methods.

Although a plethora of research focusing on aspects central to Welsh music in relation to culture, society and politics are written in Welsh (e.g. Wyn, 2006), the main language of international research and publication in the academic fields of both music and sociology is English. Consequently, both schools have limited resources available to fulfil the requirements of higher education teaching through the medium of Welsh. As a result, the module coordinators created a bibliography which included both Welsh and English sources within the field. In order to ensure that students fully understood the content of English-medium works when provided with Welsh-medium lectures, it became evident that students should be given the opportunity to develop confidence in three required translanguaging skills noted by B. Jones (2010, p.19) as reading, understanding and summarizing. As a result, seminars were included in the weekly contact hours, and students were afforded an opportunity to fully explore biliteracy practices. English-medium texts (with rare exceptions) were set in lectures, and key questions were provided as a base for thorough discussions (through the medium of Welsh) in the seminars. This opportunity would allow students to enhance their knowledge and develop a more thorough understanding of the text. This also allowed students to practice moving easily from one language to another, while also varying their use of academic literacies, i.e. switching

writing styles and genres between one setting and other, to deploy a repertoire of literacy practices appropriate to each setting, and to handle the social meanings and identities that each evokes. (Lea \& Street, 2006, p.368)

During the early stages of developing the module, it was foreseen that the variety of Welsh and English resources and references as well as the use of biliteracy skills developed whilst reading, discussing and preparing written and oral assessment would give students a 'culturally sensitive view of literacy practices' (Street, 2011,p. 61), especially as the module was directly relevant to the culture, heritage and community of Welsh-speaking students, rather than being a literal translation of a module already offered through the medium of English.

\section{Evaluation of module}

The module was developed during spring and summer 2012 and was offered for the first time to Welshspeaking students in the School of Music and School of Social Sciences, Bangor University in autumn 2012. The module was developed and validated in both schools. The module followed the usual credit weighting and teaching patterns followed by the individual schools:

Table 1: Module details.

\begin{tabular}{|l|c|c|}
\hline & Music & Sociology \\
\hline Level & $5 \& 6$ & $5 \& 6$ \\
\hline Credits & 10 credits & 20 credits \\
\hline Weekly contact hours & 1 (\& 1 optional) & 2 \\
\hline Assessment & $\bullet 7$ minute oral presentation (30\%) & $\bullet 10$ minute oral presentation (30\%) \\
\hline
\end{tabular}

Dr Gwawr Ifan, Dr Rhian Hodges, Bangor University - Error! No 


\begin{tabular}{|l|c|c|}
\hline & $\begin{array}{l}\bullet \text { Written assignment, 2500 words } \\
\text { (70\%) } \\
\text { (note: seminars not assessed for } \\
\text { music students, though students are } \\
\text { welcome to attend voluntarily) }\end{array}$ & $\begin{array}{l}\bullet \text { Written assignment 2,000 words } \\
(50 \%) \\
\text { Seminar contributions and } \\
\text { portfolio (20\%) }\end{array}$ \\
\hline $\begin{array}{l}\text { Number of students } \\
\text { on module } \\
\text { (2012/2013) }\end{array}$ & 6 & 8 \\
\hline $\begin{array}{l}\text { Number of students } \\
\text { on module } \\
(2013 / 2014)\end{array}$ & 6 & 4 \\
\hline
\end{tabular}

As shown in Table 1, for music students, this was a 10 credit module, and a 20 credit module for sociology students. As a result, sociology students were issued with an extra assessment component for seminar contributions, in which students were asked to submit a portfolio of prepared notes as evidence of general preparation, and were also marked for oral contribution. Reading lists for seminars with preparatory questions were provided at the beginning of the semester.

\section{Methodology}

The module was team-taught, with a total of 6 members of staff (including module coordinators) from both schools offering individual lectures during the semester. These were asked to provide general feedback on their teaching experiences on the module at the end of the semester. Excluding module coordinators, four members of staff were asked to provide feedback, of which two responses were received. The main source of data comes from in-depth semi-structured interviews with a combination of music and sociology students who studied the module in different years. This qualitative research strategy was chosen as it is considered that through language people can often best articulate and explain their thoughts, opinions, emotions and experiences' (Carey, 2009, p.111).

All students who participated in the module were invited to participate in the evaluation. The research methods deemed most appropriate for this evaluation were a focus group facilitated by an independent moderator and in-depth semi structured interviews with individual students. Of the cohort invited to take part in this research, six students participated in primary data collection. Three students contributed to the focus group and three students participated in in-depth interviews. All were carried out through the medium of Welsh, the usual communication language used between Welsh-speaking students and staff. Predetermined questions were set, focussing on linguistic background of students, their biliteracy processes in higher education in general, positive and negative feedback of the module, and ideas for further development. The benefits of using in-depth interviews and a focus group were that they resulted in the collection of deep, rich social data relating to the experiences, feelings and unique viewpoints of individuals (Kitzinger, 1995; Bryman, 2008) as epitomised by Prior et al:

focus groups are especially appropriate for studying public attitudes [... T] hey foster the use of participants' (rather than researcher) priorities, language and concepts. (Prior et al 2003, p.193)

The research gained ethical approval from the College of Arts and Humanities Ethics Committee and the College of Business, Law, Social Sciences and Education Ethics Committee; and the students gave their permission and informed consent to participate in the research. Ethical guidelines and protocols were 
adhered to and key principles such as confidentially and anonymity were upheld following the Data Protection Act 1998 and ESRC Social Research Guidelines.

\section{Results}

Overarching research themes are collated within the table below (see Table 2) highlighting relevant quotations from the research data. Following the table, the research themes are discussed individually. General themes regarding biliteracy are discussed at the beginning of this section, and are followed by an analysis of case study benefits and challenges.

Table 2: Primary research data quotations

\begin{tabular}{|c|c|}
\hline $\begin{array}{l}\text { Research } \\
\text { Theme }\end{array}$ & Selected quotations from primary research data (translated from Welsh) \\
\hline $\begin{array}{l}\text { Linguistic } \\
\text { background }\end{array}$ & $\begin{array}{l}\text { "English was the main social language [in school], as so many pupils come from English- } \\
\text { medium backgrounds. They were more comfortable speaking English. I spoke exactly the } \\
\text { same amount of Welsh and English growing up. Since coming to University, I only speak Welsh. } \\
\text { I'm a part of the Welsh speaking student community. (Participant no.6, music student, } \\
\text { interview). } \\
\text { "Welsh is my first language. I speak Welsh at home, and we are a bit of a mixture really, } \\
\text { because mam and dad speak English together (although they're both fluent in Welsh) but they } \\
\text { speak Welsh with my brother and I. My dad's mother is English, so maybe that's why he's } \\
\text { more comfortable speaking English. But I have been raised in a Welsh-speaking household. } \\
\text { (Participant no. 5, Music student, interview) } \\
\text { "Everyone in our family speaks Welsh. Mam, Dad and my extended family. Everybody from } \\
\text { this area speaks Welsh. You hear the Welsh language everywhere." (Participant no. 2, } \\
\text { Sociology student, interview) } \\
\text { "English is the language of my home (my grandparents speak English too). I received Welsh- } \\
\text { medium primary and secondary education." (Participant no. 3, Music student, focus group) }\end{array}$ \\
\hline $\begin{array}{l}\text { Creative } \\
\text { thinking and } \\
\text { learning }\end{array}$ & $\begin{array}{l}\text { "It makes you think more creatively to try to word something in Welsh. You have to think one } \\
\text { step in Welsh - how am I going to explain this in Welsh and make sense of it in Welsh." } \\
\text { (Participant no. 5, Music student, interview) } \\
\text { "There's more English-medium resources than Welsh-medium resources and this is true of } \\
\text { other modules, and when I was in school. I think I'm used to this by now! It's not a problem } \\
\text { by now, it makes you think more I think." (Participant no. 2, Sociology student, interview) } \\
\text { "I think it's beneficial [to be biliterate] because if the articles are available, we can read Welsh } \\
\text { and English material, and it gives us a wealth of information. Also, reading English material } \\
\text { and writing in Welsh you can express yourself in your own words." (Participant no. 1, Sociology } \\
\text { student, focus group) }\end{array}$ \\
\hline Confidence & $\begin{array}{l}\text { "I'm more comfortable speaking Welsh, but I'm more confident writing in English." } \\
\text { (Participant no. 5, Music student, interview) } \\
\text { "I'd say I was pretty confident in Welsh. I think in Welsh every time [...] I'm very comfortable } \\
\text { in English as well, but I don't have as much confidence compared to Welsh if I'm honest. I } \\
\text { would choose to do everything in Welsh [...] I hardly ever write in English... If I had to write an } \\
\text { essay in English, I wouldn't know how to put it together [...] I'd be all over the place!" } \\
\text { (Participant no. 2, Sociology student, interview) }\end{array}$ \\
\hline
\end{tabular}

Dr Gwawr Ifan, Dr Rhian Hodges, Bangor University - Error! No text of specified style in document. (3-Mar-17)
4-disciplines-A Ifan_Hodges final

(3).docx 


\begin{tabular}{|c|c|}
\hline & $\begin{array}{l}\text { "I think my Welsh and English speaking abilities are equal. I might have a little less confidence } \\
\text { speaking Welsh, and then I'll turn to English. But in terms of my written skills, my Welsh is } \\
\text { better than my English." (Participant no. 1, Sociology student, focus group) }\end{array}$ \\
\hline $\begin{array}{l}\text { Interpretation } \\
\mathbf{v} \text { translation }\end{array}$ & $\begin{array}{l}\text { "When translating English resources to Welsh, there is less chance to be guilty of plagiarism. } \\
\text { That was beneficial. It was also good to read sources from different places, so you were aware } \\
\text { of other places, and not just Wales. I tend to be quite lazy - I read and make notes in Welsh, } \\
\text { aside from quotations, and then I translate it, but in a different way." (Participant no.6, music } \\
\text { student, interview). } \\
\text { "There's a tendency to translate - not that I do this! But there's a tendency to translate word } \\
\text { for word, as it's not available in Welsh, but it's so much easier to plagiarise without } \\
\text { referencing." (Participant no. 5, Music student, interview) } \\
\text { "I try to word things differently in Welsh, and then compare back with the English. It's } \\
\text { important for me to word things in Welsh. Welsh is my language!" (Participant no. 2, } \\
\text { Sociology student, interview) } \\
\text { "The majority of the books were in English, so it was hard to analyse what the authors were } \\
\text { saying." (Participant no. 4, Music student, focus group) }\end{array}$ \\
\hline $\begin{array}{l}\text { Simultaneous } \\
\text { use of two } \\
\text { languages }\end{array}$ & $\begin{array}{l}\text { "Last semester I had to do a module completely through the medium of English and I had to } \\
\text { write the assignments in English too. But that was my choice, because it was easier! But in } \\
\text { one module, because the lecturer was Welsh speaking, I wrote the assignment in Welsh, even } \\
\text { though the lectures were in English." (Participant no.6, music student, interview). } \\
\text { "The lectures were more or less } 90 \% \text { in Welsh [...] throughout the } 3 \text { years of University; I rarely } \\
\text { read any reading material in Welsh. On the whole the majority of the material was in English." } \\
\text { (Participant no. 5, Music student, interview) } \\
\text { "I think it's OK for both languages to work together, but there should be a line drawn between } \\
\text { them, in order to separate them, which makes learning simpler and clearer.." (Participant no. } \\
\text { 2, Sociology student, interview) }\end{array}$ \\
\hline Terminology & $\begin{array}{l}\text { "Yes, a terminology handbook would be a good idea. I know one exists in the sciences, and it } \\
\text { should be available for this." (Participant no.6, music student, interview). } \\
\text { "A bilingual handbook would have been very useful." (Participant no. 5, Music student, } \\
\text { interview) } \\
\text { "A bilingual handbook would be handy especially as this is a new module, but I'm not one to } \\
\text { use English material anyway, i.e. bilingual PowerPoint slides wouldn't be very useful - I would } \\
\text { probably ignore the English material on them! The terms are important in a module like this } \\
\text { which is new for everybody. This helps us to find English terms, and it also helps us to write } \\
\text { English and Welsh terms too." (Participant no. 2, Sociology student, interview) } \\
\text { "There were terms that I wouldn't know what they were in English." (Participant no.6, music } \\
\text { student, interview). } \\
\text { "Understanding terms [...] during the lecture, we hear the terms in Welsh. If I'd have to write } \\
\text { the essay on a musical topic, then I wouldn't have known the terms." (Participant no. 1, } \\
\text { Sociology student, focus group) }\end{array}$ \\
\hline
\end{tabular}




\section{Linguistic background}

Participants were from a wide variety of geographical areas across Wales, and as a result of this their linguistic backgrounds were of a diverse nature. The one common theme which occurred was that all participants had followed Welsh-medium secondary education:

Table 3: Linguistic background of participants in interviews/focus groups.

\begin{tabular}{|l|l|l|l|l|}
\hline Participant & Main subject & $\begin{array}{l}\text { Main language spoken at } \\
\text { home }\end{array}$ & $\begin{array}{l}\text { Main } \\
\text { community } \\
\text { language }\end{array}$ & $\begin{array}{l}\text { Secondary } \\
\text { education }\end{array}$ \\
\hline 1 & Sociology & $\begin{array}{l}\text { English (Welsh with } \\
\text { Grandparents) }\end{array}$ & Welsh & Welsh \\
\hline 2 & Sociology & Welsh & Welsh & Welsh \\
\hline 3 & Music & English & English & Welsh \\
\hline 4 & Music \& Welsh & Welsh & Welsh & Welsh \\
\hline 5 & Music & $\begin{array}{l}\text { Welsh (parents speak } \\
\text { English with each other, } \\
\text { Welsh with children) }\end{array}$ & Welsh & Welsh \\
\hline 6 & Welsh & English & Welsh \\
\hline
\end{tabular}

Students noted that reading English sources in Welsh-medium education is something that they are accustomed to since secondary education, and that they are by now 'used to it ... it isn't a problem anymore.' (Participant no.6, Music student, interview). There was a clear difference in biliteracy practices and processes of students according to their linguistic background. Whilst the students from Welsh-speaking households preferred to find Welsh-medium resources first before going on to read English-medium resources, 'to ensure understanding' (Participant no.4, Music \& Welsh student, focus group), students from English-speaking households preferred to read English texts first, practicing translanguaging skills by writing notes for their assignments in Welsh. Interestingly, therefore, linguistic practices were not mainly influenced by the language of secondary education but by the language of the home.

\section{Creative thinking and learning}

In general, students considered it beneficial to actively engage biliteracy in higher education.(see quotations in table 2) When working in English they can 'enhance the way they learn', (Participant no.5, Music student, interview) and add to the depth of their knowledge by reading a broader selection of texts, which will in turn 'enrich the information they produce' (Participant no.5, Music student, interview). They also felt encouraged by their biliteracy practices to be 'more creative' when having to 'make sense of it and explain in your own words' (Participant no.6, Music student, interview). As suggested by Hibbert \& Van der Walt (2014), 'students will use the strategies and literacies they have developed up to that point to further their education'. Although reading mainly English-medium sources, students felt that writing in Welsh (the language they are most accustomed to and are most comfortable using since secondary education) allows them to 'convey it better in [their] own words.' (Participant no.4, Music student, focus group). This finding contradicts the view mentioned by Knapp (2014) that bilingual students, 'do not fully exploit their multilingual resources and that their preferred language choices tend to lead to a mere reproduction of knowledge' (p.165). Our findings suggest that through translanguaging students follow a process that requires interpretation and a deeper understanding of the subject area rather than merely surface level learning.

Dr Gwawr Ifan, Dr Rhian Hodges, Bangor University - Error! No text of specified style in document. (3-Mar-17)
4-disciplines-A Ifan_Hodges final

(3). docx 


\section{Confidence}

It became evident however that there was a tendency even amongst students from Welsh-speaking households to suffer from a lack of confidence in their written and formal English (e.g. see quotation given by Participant no.4 music students, interview, in table 2). It was a common theme for students to feel as if their choice of language influences their ability to structure and formulate assignments:

If I had to write an essay in English, I wouldn't know how to put it together ... I'd be all over the place! (Participant no. 2, Sociology student, interview)

This research highlights that a close relationship exists between a lack of language use and its impact on the confidence of a speaker. It could be argued, therefore, that a circle of dependence exists between use, confidence and perception which could possibly impact upon assessments in a wider context.

\section{Interpretation vs. translation}

Some students noted that biliteracy, especially the practice of translanguaging, adds to the amount of time it takes to prepare for assignments, and that it was more difficult to ensure they fully understand the information at hand. One student from a Welsh-speaking household noted that it was 'difficult to analyse what the author was trying to say' (Participant no. 2, Sociology student, interview) when reading English sources. Some participants even revealed the tendency to use online translating services such as Google Translate to 'get it to make sense first' (Participant no. 5, Music student, interview). However, such practice was also recognised by others as plagiarism if directly copied into their assignments, and noted that they try to avoid 'translating word for word' (Participant no. 6, Music student, interview. See further quotations regarding plagiarism in table 2).

\section{Simultaneous use of two languages}

Perhaps one of the difficulties which led to the tendency to translate was the difficulty to create a smooth flow from one language to the next in one text. Though the use of two languages in various situations was found to be beneficial at times, e.g. 'having the lectures in Welsh and the seminar texts in English' (Participant no.6, Music student, interview), it seemed to be more difficult to combine two languages. One student commented on the fact that she doesn't like to use an English quote in a Welsh essay, as 'it doesn't flow well using both languages. It's better to choose one language and stick to it.' (Participant no.5, Music student, interview. See also quotation given by participant no.2, Sociology student, interview, in table 2). As a result, students didn't always feel comfortable to use both languages freely. In particular, one student from a Welsh-speaking household felt that too many English texts were set as required readings for the seminars, and that coordinators should develop more Welsh-language sources. However, this particular student also failed to attend seminars (which were voluntary for music students) due to timetable clashes, and noted that she would probably have benefited from discussing work in Welsh (Participant no. 4, Music \& Welsh student, focus group).

\section{Terminology}

An added difficulty with biliteracy in this module was that students were introduced to a new terminology unfamiliar to them and beyond their own discipline. It was therefore more difficult for them to codeswitch and translanguage from one language to the other, as they were only familiar with the terminology in Welsh, the language used in lectures. This led to some students choosing an essay question that was more closely related to their own discipline:

Because in the lecture we would hear the terms in Welsh, if I would have chosen to write the essay on a musical topic, I wouldn't understand the terms. (Participant no. 1, Sociology student, focus group)

Dr Gwawr Ifan, Dr Rhian Hodges, Bangor University - Error! No text of specified style in document. (3-Mar-17)
4-disciplines-A Ifan_Hodges final

(3).docx 
A key research theme to emerge from the primary data was the need to develop a terminology handbook (see table 2; cf. Hurst et al.'s chapter in this book), especially as this was a new, interdisciplinary module. This was felt by music and sociology students alike, as this would equip students with the introductory knowledge and key concepts required to further develop biliteracy practices.

\section{Discussion}

For pedagogical, cultural and linguistic reasons, it seemed that students and staff alike welcomed the opportunity to have a new and different chance to work and learn in higher education.

However, suggestions were made by students regarding future development of this module and of bilingual provision in general. Despite a consensus among students that they would not welcome bilingual PowerPoint slides, care should be taken when considering resources that are available in both languages, ensuring that basic terminology is introduced to students in both languages, to allow them the freedom and ability to translanguage independently and confidently, and also to build biliteracy capacity in their new subject area. Assessment methods should also be carefully constructed to ensure confidence building. Introducing different assessment methods can offer a more varied and interesting way of educating and assessing students' understanding, allowing them the freedom to use both languages as they wish. As various students noted their lack of confidence in both written Welsh and English assignments, initial oral formative assessment may be an effective means of developing the confidence of students in working and exchanging from one language to another, expressing their ideas and findings in a language and register that is less formal and more comfortable for them. Indeed, it could be argued that oral seminar work could aid to develop the skills of students working in their second language in particular, as research focusing on Welsh learners in north Wales found that the main issues of concern for respondents was a lack of confidence, and a lack of vocabulary and pronunciation (Andrews, 2011, p.52).

Whilst this module was praised by students for the use of oral assessments in seminars, it would be beneficial for all students to attend and participate in this aspect of the assessment. Though they were well-attended by some willing music students, not all students took advantage of this opportunity. Making seminars an integral part of the module for all students would make them feel as if they were treated equally, and would avoid emphasising the divide between both disciplines. If this was successfully developed, more thought should be given to enhancing the academic socialization (Lea \& Street, 1998) of students from different disciplinary backgrounds. Even if minority-language interdisciplinary modules could serve as a means of bringing small and isolated student groups together, one could argue that the concept of academic socialization is at odds with that of interdisciplinary modules. Students may have already formed their own community within their discipline, thus it could be difficult for them to be resocialized. Thus it is the seminar facilitator's responsibility to ensure that the seminar is led in a studentcentred manner according to individual needs, whilst allowing for cross-fertilization of ideas and interdisciplinary themes.

Despite students considering seminar work interesting and effective on the whole, it seems that more work needs to be done to focus on the development of confidence for those engaging in biliteracy practices such as translanguaging when preparing for written work. Biliterate students need to be encouraged to be confident when interpreting resources in both languages, rather than the tendency of merely translating work from one language into another. Such tendencies are considered common with students working in their second language due to 'difficulties associated with L2 academic writing.'

Dr Gwawr Ifan, Dr Rhian Hodges, Bangor University - Error! No text of specified style in document. (3-Mar-17)
4-disciplines-A Ifan_Hodges final

(3).docx 
(Pecorari \& Petrić, 2014, p.270), and a lack of confidence in finding their own style, leading to the 'borrow' [ing of] language that has been used ... by someone else' (Flowerdew \& Li, 2007, p.162).

Even when working within a single discipline, it was felt that more help should be given to students studying bilingually in general, which could aid student understanding and successful assignment preparation. This, in turn, would ensure that studying bilingually strengthens their future prospects, rather than limiting their confidence and ability to use their weaker language. Instead of focussing only on course content, more emphasis could also be put on how to use two languages to develop new pedagogical strategies in higher education. These strategies could include new modes of technological communication which offer 'new ways to interact and connect with other people' (Guarda, 2012, p.23). Such help could be offered within each module, for example more contact time, one to one discussions and small formative assessments, offering examples of scholarly writing in both languages. An example of this is currently being developed by the School of Music and will be introduced during the next academic year for Music students who are following Level 4 'Astudio Cerddoriaeth' [The Study of Music] core module. ${ }^{1}$ Moreover, a Level 4 School of Social Sciences core module, 'Sgiliau Ymchwil' [Research Skills] currently includes a biliteracy skills package as a part of the module where students are assessed on translation and translanguaging practices in order to develop these essential biliteracy skills. ${ }^{2}$ This aspect of the module is facilitated by Canolfan Bedwyr, Bangor University's Centre for Welsh Language Services, Research and Technology. ${ }^{3}$ However, it would also be beneficial to consider developing a generic, multidisciplinary Welsh study skills module at College or University level, offering a wide array of skills relating to academic language use in higher education. Though such modules are currently offered to individual schools as and when required, making them available to students from different schools could give students the opportunity of being a part of a larger student group, to develop and enhance their academic community, and give tutors a wider variety of pedagogical methods of introducing information in a creative way.

\section{Conclusion}

This module introduced many different ideas to students, including assessment methods, linguistic resources and interdisciplinary themes. The evaluation of the module serves as a useful practice to consider the development of similar interdisciplinary modules for minority-language students in the future. The interdisciplinary aspect contributed to the enjoyment of students, and allowed them to get involved with a larger group of people. The teaching and assessment methods allowed for new and different approaches to biliteracy, and results show that the use of new strategies is a welcome development for students in higher education. Though a substantial amount of time and effort needs to be invested into firstly creating interdisciplinary modules, and then to evaluate and adapt the modules accordingly, positive student responses suggest that such investment is worthwhile.

Further investigation should be made into the general support that students on all Welsh-medium modules are given when working in two (or more) languages. More focussed research is also needed within single subject disciplines as biliteracy is increasingly becoming integral to the development of teaching and assessment methods and is a crucial component of pedagogical philosophy.

\footnotetext{
${ }^{1}$ For further details, see www.bangor.ac.uk/music/undergraduate-modules/WXC-1001.

${ }^{2}$ For further details, see http://www.bangor.ac.uk/so/undergraduate-modules/SCU-1001

${ }^{3}$ For further details see http://www.bangor.ac.uk/canolfanbedwyr/index.php.en 


\section{References}

Adeyemni, D. (2010). Justification of a multidisciplinary approach to teaching language in Botswana junior secondary schools. The Journal of Language, Technology \& Entrepreneurship in Africa, 2, 1: 8-20.

Andrews, H. (2011). Llais y dysgwr: Profiadau oedolion sydd yn dysgu Cymraeg yng ngogledd Cymru. Gwerddon, 9: 37-58.

Baker, C. (1993). Bilingual education in Wales. In: H. Baetens Beardsmore (ed.), European models of bilingual education (7-29). Clevedon: Multilingual Matters.

Bangor University (2013). Bangor University Welsh Language Scheme: Prepared in accordance with the Welsh Language Act 1993. Retrieved 20 March 2015 from www.bangor.ac.uk/canolfanbedwyr/pdf/LS_Saesneg_2013.pdf.

Bryman, A. (2008) Social Research Methods. Oxford: Oxford University Press.

Carey, M. (2009). The social work dissertation: using small-scale qualitative methodology. Maidenhead: Open University Press.

Clapham, J. (2012). Dadansoddiad o ddefnydd athrawon dan hyfforddiant o gyfnewid cod mewn dosbarth uwchradd dwyieithog: achos o Gymru. Gwerddon, 10/11: 159-195.

Coleg Cymraeg Cenedlaethol (2014a). What is the Coleg Cymraeg Cenedlaethol? Retrieved 20 March 2015 from

www.colegcymraeg.ac.uk/en/media/main/pdfs/informationleaflets/CCC_GeneralLeaflet_2014_E nglish_pdf.

Coleg Cymraeg Cenedlaethol (2014b). Undergraduate Prospectus. Retrieved 20 March 2015 from www.colegcymraeg.ac.uk/en/media/main/pdfs/CCC_EnglishProspectus_2014.pdf.

Davies, A J \& Trystan, D. (2012), 'Build it and they shall come?' an evaluation of qualitative evidence relating to student choice and Welsh-medium higher education. International Journal of Bilingual Education and Bilingualism, 15(2),147-164.

Flowerdew, J. \& Li, Y. (2007). Plagiarism and second language writing in an electronic age. Annual Review of Applied Linguistics, 27: 161-183.

García, O. (2009). Education, multilingualism and translanguaging in the 21st century. In Mohanty, A., Panda, M., Phillipson, R. \& Skutnabb-Kangas, T. (eds.), Multilingual education for social justice: globalising the local. New Delhi: Orient Blackswan, pp. 140-158.

Grabe, W. (1989). Literacy in a Second Language. Annual Review of Applied Linguistics 10: 145-162. Grout, D. \& Palisca, C. (1997). Hanes Cerddoriaeth y Gorllewin. Cardiff: Gwasg Prifysgol Cymru.

Guarda, M. (2012) Computer-Mediated-Communication and Foreign Language Education, Journal of ELearning and Knowledge Society, 8(3), 15-37.

Hibbert, L \& Van der Walt, C. (2014) Biliteracy and Translanguaging Pedagogy in South Africa: An Overview in Hibbert, L \& Van der Walt, C (eds.) Multilingual Universities in South Africa: Reflecting Society in Higher Education (pp 3-14). Bristol, Tonawanda \& Ontario: Multilingual Matters.

Higher Education Funding Council for Wales (2004). Steering Group for Welsh medium provision in higher education. Retrieved 10 March 2015 from

www.hefcw.ac.uk/documents/policy_areas/welsh_medium/Strategy\%20for\%20Strat\%20Fmwk\% 20page.pdf.

Hodges, Rh. (2012). Welsh-medium education and parental incentives: the case of the Rhymni Valley, Caerffili. International Journal of Bilingual Education and Bilingualism, 15, 3: 355-373.

Hornberger, $N$ (2007). Biliteracy, transnationalism, multimodality, and identity: Trajectories across time and space. Lingust Educ, doi:10.1016/j.linged.2007.10.001.

Dr Gwawr Ifan, Dr Rhian Hodges, Bangor University - Error! No text of specified style in document. (3-Mar-17)
4-disciplines-A Ifan_Hodges final

(3).docx 
Hornberger, N. \& Link, H. (2012). Translanguaging in today's classrooms: a biliteracy lens. Theory Into Practice 51, 4: 239-247.

Huang, G.G. (1995). Self-reported biliteracy and self-esteem: a study of Mexican American 8th graders. Applied Psycholinguistics, 16: 271-291.

Jones, B. (2010). Amrywiaeth Caleidosgopig: addysg ddwyieithog yng Nghymru heddiw. Gwerddon 5: 926.

Jones, G.R (2010) 'Factors influencing choice of higher education in Wales', Contemporary Wales, 23, 1: 93-116.

Julian, K., O'Sullivan, P. S., Vener, H. H., \& Wamsley, M. A. (2007). Teaching residents to teach: the impact of a multi-disciplinary longitudinal curriculum to improve teaching skills. Med Educ Online 12: 12.

King, C.J. (2010) The multidisciplinary imperative in higher education. Research \& Occasional Paper Series: Centre for Studies in Higher Education. Retrieved on 10 March 2015 from http://cshe.berkeley.edu/sites/default/files/shared/publications/docs/ROPS.\%20King.Multidiscip linary.9.13.10.pdf.

Kitzinger, J. (1995) Qualitative Research: Introducing focus groups. British Medical Journal. 311. 299-302.

Knapp, A. (2014) Language choice and the construction of knowledge in higher education. European Journal of Applied Linguistics 2, 2: 165-203.

Lea, M.R. \& Street, B.V. (2006).The "Academic Literacies" model: theory and applications. Theory Into Practice, 45, 4: 368-377.

Lewis, G. (2011). Addysg Ddwyieithog yn yr unfed ganrif ar hugain: adolygu'r cyd-destun rhyngwladol. Gwerddon, 7: 66-88.

Malarz, L. (1998). Bilingual education: Effective Programming for Language-Minority Students in Curriculum Handbook (Association for Supervision and Curriculum Development). Retrieved on 2 March 2015 from ascd.org/publications/curriculum_handbook/413/chapters/Bilingual_Education@_Effective_Prog ramming_for_Language_Minority_Students.aspx.

Office for National Statistics (2011). Census: Key Statistics for Wales.) Retrieved on 3 March 2015 from http://ons.gov.uk/ons/rel/census/2011-census/key-statistics-for-unitary-authorities-inwales/stb-2011-census-key-statistics-for-wales.html

Pecorari, D. \& Petric, B. (2014). Plagiarism in second-language writing. Language Teaching 47, 3: 269302.

Prior, L., Wood, F., Lewis, G. \& Pill, R. (2003) Stigma revisited: disclosure of emotional problems in primary care in Wales. Social Science and Medicine, 56, 2191- 2200.

Reyes, I. (2006). Exploring connections between emergent biliteracy and bilingualism. Journal of Early Childhood Literacy 6, 3: 267-292.

Robert, E. (2009). Accommodating new speakers? An attitudinal investigation of $L 2$ speakers of Welsh in south-east Wales. International Journal of the Sociology of Language, 195: 93-115.

Street, B. (2011). 'New Literacy Studies and the Continua of Biliteracy' in Hult., F \& King K. (eds.), Educational linguistics in practice: applying the local globally and the global locally. Bristol, Tonawanda \& Ontario: Multilingual Matters.

Thomas, H \& Williams, C.H. (eds.) (2013). Parent, Personalities and Power: Welsh-medium Schools in South-east Wales. Cardiff: University of Wales Press.

Welsh Government (2010). Welsh-medium Education Strategy. Retrieved on 1 March 2015 from gov.wales/docs/dcells/publications/100420welshmediumstrategyen.pdf.

Dr Gwawr Ifan, Dr Rhian Hodges, Bangor University - Error! No text of specified style in document. (3-Mar-17)
4-disciplines-A Ifan_Hodges final

(3).docx 
Welsh Government (2013). National Literacy and Numeracy Framework. Retrieved on 1 March 2015 from learning.wales.gov.uk/docs/learningwales/publications/130415-Inf-guidance-en.pdf.

Welsh Government and Welsh Language Commissioner (2015). Welsh Language Use in Wales 2013-2015. Cardiff: Welsh Government and Welsh Language Commissioner.

Williams, C. (1994). Arfarniad o ddulliau dysgu ac addysgu yng nghyd-destun addysg uwchradd ddwyieithog. Unpublished PhD thesis. Bangor: University of Wales.

Wyn, H. (2006). Ble wyt ti rhwng? Hanes canu poblogaidd Cymraeg 1980-2000. Talybont: Y Lolfa.

\section{Author(s):}

Dr Gwawr Ifan, Coleg Cymraeg Cenedlaethol lecturer of Music, School of Music, Bangor University.

Dr Rhian Hodges, Coleg Cymraeg Cenedlaethol lecturer of Sociology and Social Policy, School of Social Sciences, Bangor University. 